\title{
MUSLIM MILLENNIAL'S INTENTION OF DONATING FOR CHARITY USING FINTECH PLATFORM
}

\author{
Farokhah Muzayinatun Niswah ${ }^{1}$, Lu'liyatul Mutmainah² and Diah Ayu Legowati ${ }^{3}$ \\ ${ }^{1}$ University of Indonesia, Indonesia, faroh.blue@gmail.com \\ ${ }^{2}$ University of Indonesia, Indonesia, sakinah.lym@gmail.com \\ ${ }^{3}$ University of Indonesia, Indonesia, ayuudiahh@gmail.com
}

\begin{abstract}
Financial Technology (fintech) has been a part of human life. Fintech becomes a solution of human needs without limits of space and time and makes it easy for people, especially the millennials, to make donation. This study aims to explore the factors that influence Muslim millennial's intention in giving donation using fintech. This study uses an integration model of Technology Acceptance Model (TAM) and Theory of Planned Behavior (TPB). Online survey is used in this research including 115 Muslim millennials as sample. Data analyzed by Structural Equation Model (SEM) using Smart PLS. The results indicate that Perceived Usefulness (PU) and Perceived Ease of Use (PEOU) have no significant effect on Attitude Towards Usage (ATU), Attitude Towards Usage (ATU) has no significant effect on Behavioral Intention (BI), Perceived Usefulness (PU), Subjective Norm (SN) and Perceived Behavioral Control (PBC) significantly have a positive effect on Behavioral Intention (BI). Overall, fintech improves Muslim millennial's intention to make donation easily and almost all of respondents know about fintech, even not all of the use fintech to donate. This research contributes both theoretically and practically.
\end{abstract}

Keywords: Fintech, Donation, Millennial, Intention.

JEL Classification: A13; B26; D03; 016.

Article history:

Received : :September 5, 2019

Revised : : September 15, 2019

Accepted : : October 22, 2019

Available online : November 1, 2019

https://doi.org/10.21098/jimf.v5i3.1080 


\section{INTRODUCTION}

\subsection{Background}

Global network with high technology develops significantly break any boundaries of time and place. One of the innovations in this global era is financial technology. Financial technology becomes recent most topics in this recent year. Financial technology or Fintech is a digitization of financial service that adopts the use of technology and creates new business model. Fintech grows significantly in this era of 4.0-industry revolution to shift people behavior and mindset. Financial Technology or fintech is one of the economic sectors with the largest growth. Investment in this industry increased rapidly to reach $\$ 12.2$ billion in 2014, while in 2008, it only reached \$930 million (Saksonova and Merlino, 2017: 963) and in 2018 the global investment in fintech companies reached $\$ 111.8$ billion with 2,196 deals (KPMG, 2019).

Fintech is defined as the use of new technology and innovation to compete in marketplace of financial institution and intermediaries (Fenwick et al., 2017). Fintech is a cross-disciplinary subject that combines finance, technology management and innovation management. Fintech provides new perspective for evaluating business model (Leong and Sung, 2018). As far as fintech is concerned, crowd funding is a relevant subject that cannot be separated from the discussion of technology-based fundraising mechanisms.

Crowdfunding is gathering funds for certain purpose using the Internet. Even though crowdfunding relies on collecting small amount of contribution, but when a large number of people donate, the amount becomes a significant funding. Variations of the crowdfunding are investment and philanthropy. Therefore, this research focuses on the philanthropic cases, especially in donations for charity or social purposes.

World Giving Index Score (2018) named Indonesia as the most philanthropist people in the world. With a population about 260 million people, Indonesia is one of the largest population in the world and has potential to gather tremendous amount of funds for donations. Data from Pew Research Center (2011) showed that estimated Muslim population in Indonesia is $88.1 \%$ (204.847.000 people) in 2010 and projected Muslim population in 2030 is 88\% (238.833.000 people). On the other hand, Muslim has obligation to pay zakah. The potential of zakat in Indonesia is IDR 216.54 trillion or equivalent to $1.75 \%$ of GDP. The amount is based on contemporary fiqh approach under optimistic scenario assumes that all Muslims pay zakat (Asfarina et al., 2019). Besides, Islam also suggests giving donation or sadaqah for all Muslim. Nowadays, Muslim can donate not only in a mosque or an orphanage, but anywhere and without any cash. They could use their phones using website, an application, e-banking platforms, or other features to donate, such as fintech.

Indonesia has a huge Internet penetration with $56 \%$ urban population. Mobile subscriptions in Indonesia reach up to $133 \%$ from the population, $56 \%$ Internet and active social media user penetration, and $48 \%$ of mobile social media users (We Are Social, 2019). Indonesia is expected to add 50 million new Internet users from 2015 to 2020 , reaching a penetration rate of $53 \%$. Approximately, $73 \%$ of total Internet users access via mobile and $75 \%$ of the online purchases are made via mobile devices. Indonesia also has $90 \%$ Internet users who visit Facebook and 
spend time on social media about 2.9 hours per day (McKinsey \& Company, 2016). Indonesia is one of many countries in transitionary cluster with score of $61.4 \%$ in 2018. Transitionary, or a score above 50, is cluster that performs well on at least two enables and generally has mobile Internet penetration between $30 \%$ up to $50 \%$ (GSMA, 2019). One of many users of the digital services is millennial generation who can learn and accept technology usage in their daily activities.

Digital service development offers various daily needs of people, as it delivers some information for users and creates engagement between them. Similarly, fintech services for donations serve as an alternative, that is, once we donate using fintech, it will send us upcoming information about people requiring help.

Studies in information technology adoption and behavior intention are usually drawn in business. However, very limited studies within the relevant theories explore behavioral intention in social or charity fields, such as using fintech for donation (Chen et al., 2019). Previous studies only investigated customer's perspective and its potential to use fintech service in general (Chuang et al., 2016), payment (Kim et al., 2016), and Islamic fintech (Rusydiana, 2018). Meanwhile, Ryu (2017) tried to establish determinants of using fintech. Putu et al., (2018) and Muzdalifa et al. (2018) related fintech usage for MSMEs. Finally, Rahma (2018) used a different method to find public perception in using fintech.

Unfortunately, very few studies explore the social funding potential among Muslim millennials' generation who are more exposed to technology, especially for financial purpose. Fintech is an innovative high-tech product, therefore fintech area used as a study subject with Technology Acceptance Model (TAM) and Theory of Planned Behavior (TPB) used to investigate Muslim millennial's attitude in using fintech for donation can become an important issue.

\subsection{Objective}

This research aims to explore the factors that influence Muslim millennial's intention in providing donation using fintech. Specifically, the study has two objectives. First, this study attempts to explore the awareness of using fintech among Muslim millennial's generation. Second, this study endeavors to examine the impact of TAM and TPB theories to Muslim millennial's intention to donate trough fintech.

\section{LITERATURE REVIEW}

\subsection{Background Theory}

\subsubsection{Financial Technology and Millennial Generation}

Fintech is an integration of technology and financial features, which change a business model. Financial Stability Board (2019) states that fintech firms have typically found new niches e.g. platforms for peer-to-peer lending (P2P lending), crowdfunding, and cross-border payments- and underserved clients, for example small business or people who lack of credit history. Fintech is an innovative technology-based financial service that is efficient, low cost, improves business processes, fast, flexible, and innovative (Dapp et al. 2014). Fintech is also defined as a company that combines innovative business models and technologies to enable, improve and disrupt financial services (Gulamhuseinwala et al., 2015). 
Crowdfunding is a digital economy where funds are collected from many individuals (the crowd) and distributed using online platforms to recipients or institutions (Langley, 2016). Crowdfunding quickly grows in a short time (Langley \& Leyshon, 2017). This mechanism allows dozens or hundreds of people together to realize a commercial and social project. Crowdfunding platforms categorized into four models: 1) The donation model, donation contributors do not expect compensation for their contribution; 2) The reward and pre-purchase model, offering an imbalance contributor to its contribution, contributors are offered non-financial return, but promised only for the product or service; 4) The lending model, provides temporary funding and expects the return of loan; 5) Equity model, giving return to contributors for some sort of revenue or profit-sharing (Bradford, 2012; Fenwick et al., 2017). When people provide the donation-based crowdfunding model, they generally contribute to social, charitable or social project without expectation of being compensated (Fenwick et al., 2017).

Millennial is the terminology of a generation that is currently being discussed by many in the world in various fields. Karl Mannheim (1952) the millennial generation is the generation born in 1980 to 2000. Millennials are also referred as Y generation (Pyöriä et al., 2017). Therefore, it can be concluded that the millennial generation is the generation that is currently 19-39 years old.

\subsubsection{Technology Acceptance Model (TAM)}

Davis (1989) introduced Technology Acceptance Model (TAM) as an adaption of Theory of Reasoned Action (TRA). TAM is a theory that offers a foundation for learning and understanding user behavior in receiving and using an information system. Furthermore, TAM is expected to predict individual attitude and acceptance of technology and can provide basic information needed regarding the factors that motivate the individual attitude. According to Venkatesh and Davis (2000) in TAM, individual intention to use technology is determined by two factors that are perceived usefulness and perceived ease of use. Perceived usefulness is the level trust of someone that the use of technology will improve performance. While perceived ease of use is the level trust of someone that using technology makes easier to complete work.

\subsubsection{Theory of Planned Behavior (TPB)}

Theory of Planned Behavior (TPB) was developed based on the Theory of Reasoned Action (TRA) (Fishbein \& Ajzen, 1975). The basic difference between TRA and TPB is existence addition of one element in the model that is perceived behavioral control. TPB has three main factors as determinants of intention. First, attitudes reflect the extent to which individuals have an assessment of agree or disagree to do a behavior. Second, a social factor serves as a subjective norm referred to as the social pressure of someone felt to do or not do a behavior. Third, perceived behavioral control plays the role of the perceived ease or difficult doing behavior (Ajzen, 1991). 


\subsection{Previous Studies}

Some previous studies can be explored and supported this study. First, Putu et al. (2018) investigated the readiness of MSMEs on services offered by fintech related to funding activities, found the role of fintech in the development of MSMEs and the national financial system, risk management, and also governance models that were in line with the fintech business. He finds that the majority of MSMEs from around $81.8 \%$ of respondents are ready to use fintech. Regulators need to consider socializing the use of fintech in transactions to increase the role of fintech as a source of funding for MSMEs. The design of fintech governance and risk management models in this study must adopt an IT governance framework including strategy regret, delivery of trust values, HR management, business and IT risk management, and employee management.

Second, Muzdalifa et al. (2018) analyzed the role of fintech in increasing financial inclusion in MSMEs. The findings show that the presence of fintech contributes to the development of MSMEs. Not only in the form of financing, but also in digital payment services and financial arrangements. The obstacles for implementing fintech in inclusive finance for MSMEs in Indonesia are infrastructure, human resources, regulation, and lack of financial literacy.

Third, Chuang et al. (2016) analyzed consumer behavior intentions in using fintech services. The results show that brand trust and service have a significant positive effect on attitudes in using fintech services. The perceived benefits have a significant positive effect on attitudes towards usage. Perception of ease of use has a significant positive effect on attitudes. Attitudes toward usage have a significant positive effect on behavioral intention to use.

Fourth, Rusydiana (2018) researched the problems, foundations and keys or stakeholders involved in developing Islamic fintech in Indonesia. His research show that that the core problems faced in developing the Islamic finance technology industry are lack of policy instruments that maintain the work process of fintech and the availability of human resources for fintech. The strategy needed in the framework of developing Islamic fintech is the ability to manage and analyze data in the era of big data and human resources in digital marketing. Actors that involved in the development of Islamic fintech in Indonesia are the government or regulator, educational institution and industry.

Fifth, Ryu (2017) investigated the reason why people want to use or are hesitant in using fintech and determined whether the influence of perceived usefulness and the risk of intention of continuing to use depend on the type of user. The results conclude that legal risks have the most negative effect on the intention to continue using fintech, while comfort has the strongest positive effect.

Sixth, Rahma (2018) determined the public perception of the use of fintech. She finds that community attitudes towards the use of fintech provided support for the advancement of financial technology innovation in Indonesia, which greatly helped the community, while the interest of the community to use fintech was proven by the results of interviews 9 out of 10 respondents were interested in using it. The community has understood the benefits of using because it is more efficient and effective than other financial services which community become motivated to use fintech. 
Seventh, Kim et al. (2016) examined the acceptance of fintech service types of payments from users by using the elaboration likelihood model and TAM. They also analyzed the causal relationship between concern for information privacy and self-efficacy as a moderating variable. They conclude that usability, ease of use and credibility have a relation to the intention to use and self-efficacy to have a moderating effect on the dependent and independent variables. The implication of this research is that in fintech service promotion of payment types, convenience and usability are the most important and influential variables in terms of usage.

Eighth, Won-Jun (2018) figured out factors affecting bitcoin acceptance. The interest behavior of using bitcoin is influenced by the perception of benefits and security. This research shows that perceived convenience has no significant effect and only indirectly influences intention.

From previous studies explained that the use of TAM and TPB not always showed the same results, it depends on subject and the object of the study. Researchers also find that here is no research that investigates the Muslim millennial's intention to donate using fintech. Other past researches are mostly about fintech for the other subjects and they are not about the use of fintech to make donation.

\section{METHODOLOGY}

\subsection{Data}

The collected data in this research used primary and secondary data. Secondary data was obtained from related literature both from books, information on websites, as well as previous researches. While the primary data obtained using questionnaires. Questionnaires are made using online survey. The sampling technique used in this study is the Convenience Sampling Method.

The sample criteria in this study were Muslim in millennial generation (birth in year of 1980-2000). The questions used as indicators in this study are based on theory and previous researches that are relevant to this research's topic. PLS-SEM is often used for small sample sizes and complex models (Hair, et al., 2012), with minimum size is "ten times rule" (Reinartz, 2009). Therefore, in this research, the minimum sample size is $6 \times 10=60$ samples. Based on the scattered questionnaire, 115 questionnaires had met the requirements and were used as sample in this study.

Five-point Likert scales ranging from "strongly disagree" to "strongly agree" were used as a base of the questions. This scale has been used in previous TAM and TPB related research (Chuang et al., 2016; Ryu, 2017; Rahma, 2018). Each respondent was asked to show his agreement or disagreement in each statement submitted in the questionnaire. The statement used as an indicator in this study is based on theory and previous research that is relevant to the research topic using the basic framework of Theory of Acceptance Model (TAM) and Theory of Planned Behavior (TPB). The Structural Equation Modeling-Partial Least Square (SEM-PLS) method used and SmartPLS 3 application will be used to process the research data. 
Subjective Norm (SN) is a social pressure that is a feeling to donate using fintech or not. Perceived Behavioral Control (PBC) is ease or difficulty that someone feels in giving donation using fintech and assumed to reflect their past experiences and obstacles that they anticipated. Perceived Usefulness (PU) is the extent to which someone believes that using a fintech will be able to improve his or her work performance. Perceived Ease of Use (PEOU) is a measure of the extent to which someone believes that using fintech will be free of effort. Attitude Towards Usage (ATU) is the extent to which someone evaluates donation using fintech is liked or disliked. Behavioral Intention (BI) is an indication of how hard someone wants to try, how much effort to plan to donate using fintech and factors that influence someone to donate using fintech.

\subsection{Model Development}

Technology Acceptance Model (TAM) in this study was used as a base conceptual for donations using fintech that has sprung up in the community. The main factor found in TAM is Perceived of Usefulness (PU) and Perceived Ease of Use (PEOU), which will affect someone's attitude to donate using fintech (Attitude Towards Usage/ATU). While intention or behavioral intention to donate using fintech (Behavioral Intention/BI) is the factor that can determine whether the user really makes donations using fintech.

Theory of Planned Behavior (TPB) was also used in this research, together with TAM. TAM is an adaptation of the Theory of Reasoned Action (TRA), while Theory of Planned Behavior (TPB) is the development of TRA. The TPB model shows that attitude, subjective norm and perceived behavioral control are direct determinants of behavioral intention, which in turn affects someone behavior. The decomposed TPB model has similar advantages to TAM in identifies specific salient beliefs that may influence information technology usage (Taylor \& Todd, 1995).

The use of the TAM and TPB model to understand millennial perceptions of the use of fintech to donate can be assumed as follows:

1. When millennial consider donations using fintech to be useful, it is possible that they will have a positive attitude towards using fintech.

2. When millennial think donations using fintech are something that is easy to use, there is a possibility that they will have a positive attitude towards using fintech.

3. When millennial consider donations using fintech to be useful, there is possibility that they will have a positive intention towards using fintech to make donations.

4. When millennial has a positive attitude towards using fintech to donate, they can use it routinely and intensively and may have a positive intention to use it.

5. When millennial believe that their peers think that they should use fintech to make donations, it is possible that they will have a positive intention towards using fintech to make donations.

6. When millennial feel that they have the skill to use fintech to make donations, there is a possibility that they will have a positive intention towards using fintech to make donations. 
Figure 1.

Research Framework

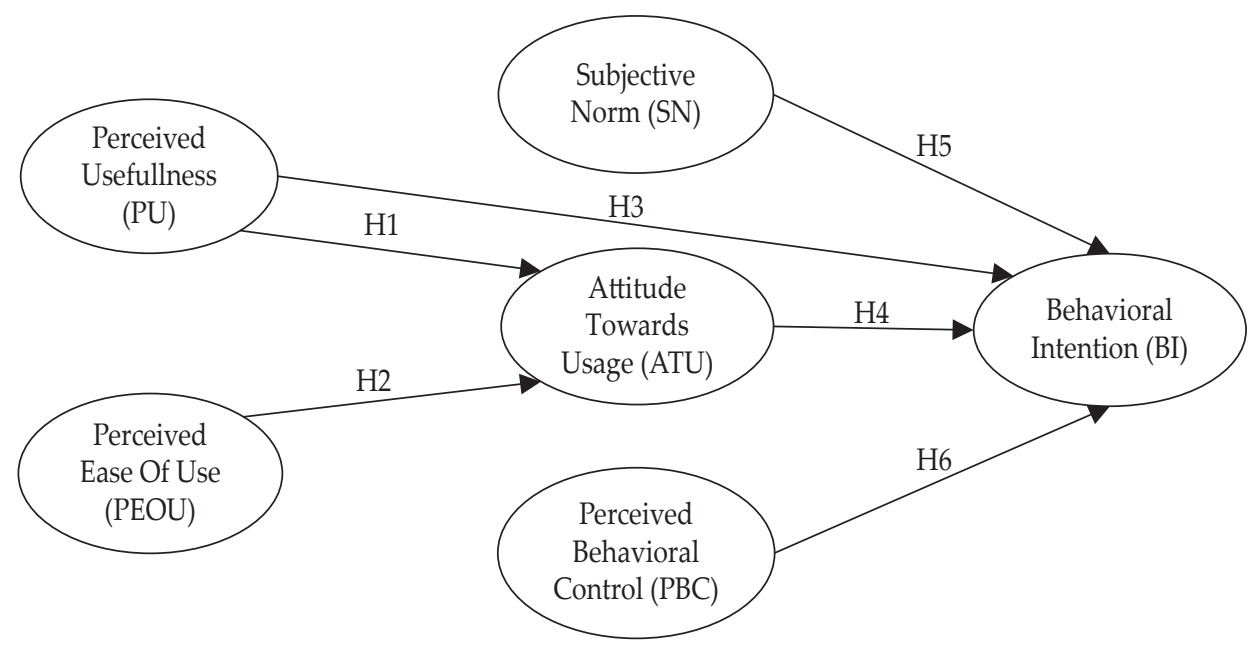

Source: Authors

There are six hypotheses that are developed in this research, they are:

$\mathrm{H}_{1}$ : Perceived Usefulness (PU) significantly has a positive impact towards Attitude Towards Usage (ATU) of fintech to donate.

$\mathrm{H}_{2}$ : Perceived Ease of Use (PEOU) significantly has a positive impact towards Attitude Towards Usage (ATU) of fintech to donate.

$\mathrm{H}_{3}$ : Perceived Usefulness (PU) significantly has a positive impact towards Behavioral Intention (BI) of using fintech to donate.

$\mathrm{H}_{4}$ : Attitude Towards Usage (ATU) significantly has a positive impact towards Behavioral Intention (BI) of using fintech to donate.

$\mathrm{H}_{5}$ : Subjective Norm (SN) significantly has a positive impact toward Behavioral Intention (BI) of using fintech to donate.

$\mathrm{H}_{6}$ : Perceived Behavioral Control (PBC) significantly has a positive impact towards Behavioral Intention (BI) of using fintech to donate.

There are 20 indicators of latent variables in this research as follows:

Table 1.

The Variable Indicators

\begin{tabular}{lll}
\hline Variable & \multicolumn{1}{c}{ Indicator } & \multicolumn{1}{c}{ Source } \\
\hline SN & Influential people can influence & Venkatesh \& Davis, 2000; Venkatesh et \\
& someone's behavior & al., 2012 \\
& Important people can influence & Venkatesh \& Davis, 2000; Venkatesh et \\
& someone's behavior & al., 2012; Taylor \& Todd, 1995 \\
& People whose opinions are important & Venkatesh et al., 2012; Taylor \& Todd, \\
& can influence someone's behavior & 1995 \\
\hline
\end{tabular}


Table 1.

The Variable Indicators (Continued)

\begin{tabular}{lll}
\hline Variable & \multicolumn{1}{c}{ Indicator } & \multicolumn{1}{c}{ Source } \\
\hline PBC & $\begin{array}{l}\text { Willingness to use } \\
\text { Do the behavior without coercion } \\
\text { Have resources, knowledge, and ability } \\
\text { to use }\end{array}$ & $\begin{array}{l}\text { Taylor \& Todd, 1995 } \\
\text { Taylor \& Todd, 1995 } \\
\text { Taylor \& Todd, 1995 }\end{array}$ \\
\hline POU & Accelerates the work & Davis, 1989 \\
& More effective & Davis, 1989; Venkatesh \& Davis, 2000; \\
& Pikkarainen et al., 2004 \\
& Makes work easier & Davis, 1989; Pikkarainen et al., 2004 \\
& Useful & Davis, 1989; Venkatesh \& Davis, 2000; \\
& Pikkarainen et al., 2004; Taylor \& Todd, \\
& 1995 \\
\hline PEOU & Easy to learn & Davis, 1989; Pikkarainen et al., 2004 \\
& Clear and easy to understand & Davis, 1989; Venkatesh \& Davis, 2000; \\
& Pikkarainen et al., 2004 \\
& Flexible to use & Davis, 1989; Pikkarainen et al., 2004 \\
& Easy to use & Davis, 1989; Venkatesh \& Davis, 2000; \\
& Pikkarainen et al., 2004 \\
\hline ATU & Convenient to use & Chuang et al., 2016; Taylor \& Todd, 1995 \\
& It is a good idea to use & Chuang et al., 2016; Taylor \& Todd, 1995 \\
& Like the idea of using & Chuang et al., 2016; Taylor \& Todd, 1995 \\
\hline BI & Intention to use in near future & Taylor \& Todd, 1995 \\
& Intention to use & Taylor \& Todd, 1995 \\
Intention to repeatedly use (onwards) & Taylor \& Todd, 1995 \\
\hline
\end{tabular}

Source: Authors

\subsection{Method}

The questionnaire data were analyzed based on Structural Equation Method - Partial Least Squares (SEM-PLS). SEM-PLS is one kind of structural equation method based on variance. PLS is suitable for explanative or predictive researches (Henseler, et al., 2016). PLS is a part of regression-based methods to analyze the high dimensional data in a low-structure environment (Vinzi et al., 2010). PLS deals with abnormal data, small sample sizes, and formally measured constructions (Hair et al., 2014). PLS consists of two linear equations, i.e., the measurement model (outer model) that determines the relationship between constructs and observed indicators and structural model (inner model) that determines the relationship between constructs (Henseler, et al., 2016).

The questionnaire data should pass the reliability test and validity test. The data is valid if they are able to measure what is desired (Nasution and Usman, 2007). While reliability test indicates the stability and consistency of the measurement instruments of a concept and helps to see the accuracy of measurements. Validity test is done by looking at the value of Cronbach's Alpha (Nasution and Usman, 2007). An item is declared valid if the significance value is $(\alpha) 0.05$ or less (Gujarati, 2004). Meanwhile, another is declared consistent and reliable if the loading indicator is 0.70 or more (Hulland, 1999). 


\section{RESULTS AND ANALYSIS}

\subsection{Results}

\subsubsection{Demographic Information}

Demographic information of this research's sample was illustrated in Table 1. This research also provides the level of monthly income, expenditure, and amount of donations among participants. In Addition, it provides the level of literacy about fintech and the type of fintech brand used by participants. Perhaps, it can uncover how Muslim millennial's intention makes donation using fintech with their condition.

Table 2.

Demographic Information of The Participants

\begin{tabular}{llcc}
\hline \multicolumn{2}{c}{ Characteristic N=115 } \\
\hline Variable & \multicolumn{1}{c}{ Description } & Frequency & Percentage (\%) \\
\hline Gender & Female & 78 & $68 \%$ \\
& Male & 37 & $32 \%$ \\
\hline Age & 19 - 23 years old & 30 & $26 \%$ \\
& 24 - 29 years old & 67 & $58 \%$ \\
& 30 - 34 years old & 12 & $10 \%$ \\
& 35 - 39 years old & 6 & $5 \%$ \\
\hline Education & Senior High School & 11 & $10 \%$ \\
& Undergraduate & 81 & $70 \%$ \\
& Postgraduate & 22 & $19 \%$ \\
& Doctoral & 1 & $1 \%$ \\
\hline Occupation & Student & 49 & $43 \%$ \\
& Civil Servant & 9 & $8 \%$ \\
& Private Employee & 19 & $17 \%$ \\
& Entrepreneur & 6 & $5 \%$ \\
& Teacher/Lecturer & 14 & $12 \%$ \\
& Wifehouse & 3 & $3 \%$ \\
& Others & 15 & $13 \%$ \\
\hline Region & Jabodetabek (Jakarta, & & \\
& Bogor, Depok, & $53 \%$ \\
\hline & Tangerang, Bekasi) & 56 & $49 \%$ \\
& Outside Jabodetabek & & \\
& (but in Java) & 6 & $5 \%$ \\
\hline & Not in Java & &
\end{tabular}

Source: Authors

This study involved 115 respondents from Muslim Millennials in Indonesia, consist of $68 \%$ (78 people) women and 32\% (37 people) men. The majority of respondents aged between 24 years -29 years about 58\% (67 people) and at least 35 years - 39 years old about 5\% (6 people). Respondents were predominantly millennials who obtained community college degrees or university undergraduate degrees (70\% or 81 people). Only $1 \%$ or one person was of a doctoral background. 
The Muslim Millennials are dominated by students as much as $43 \%$ (49 people) and at least 3\% housewives (3 people). 46\% respondents lived in Jakarta and the vicinity area (Jabodetabek), 49\% outside Jabodetabek, and 5\% outside Java Island.

Monthly income of the respondents in the study was dominated by income between 2.5 million and below 5 million rupiah as much as 30\% (34 people), and at least 5 million up to 7.5 million rupiahs about $11 \%$ (13 people). While the level of expenditure per month is at most between 1 million to under 2.5 million rupiah, which is $37 \%$ (43 people), the lowest expenditure is from 5 million to under 7.5 million rupiah and more than 7.5 million rupiah $4 \%$ (5 people).

The amount of donations issued every month is mostly below or equal to 100 thousand rupiah, which is $46 \%$ (53 people) and the lowest is between 600 thousand to under 1 million rupiah and more than 1 million rupiah is $4 \%$ (5 people). Based on the level of income, expenditure and donation issued each month, the results show that there is consistency with high income and expenditure, as their donations are higher than other levels of income and expenditure. Meanwhile, the frequency of donations made per month shows that the majority of millennials donated 2 to 4 times as many as 59\% (68 people) and at least donated more than 10 times a month, which is $5 \%$ (6 people).

Based on the research related to fintech literacy, $90 \%$ (104 people) of respondents knew fintech while $10 \%$ (11 people) of them did not know. However, only $58 \%$ (67 people) understood the difference between Islamic fintech and fintech, while $42 \%$ (48 people) did not. When the respondents were given various fintech logos, 97\% (111 people) claimed to have known the various logos, while 3\% (4 people) did not know about the logo. In addition, 92\% (106 people) of respondents have used fintech both using website and application, while $8 \%$ (9 people) have never. It indicates that not all respondents knew fintech had used fintech, it can be seen from the number of people who did not know as many as 4 people, but who never used as many as 9 people. However, the majority of respondents already have literacy related to fintech and have used it.

The next data related to donations using fintech shows that only 57\% (65 people) of respondents have ever donated using fintech, while $43 \%$ (50 people) have never used it. Then, the next data shows that all respondents have used fintech both based on website and application, even most of them use more than one fintech brands. The following is the fintech data used by respondents: 
Figure 2.

Amount of The Usage of Fintech's Brand

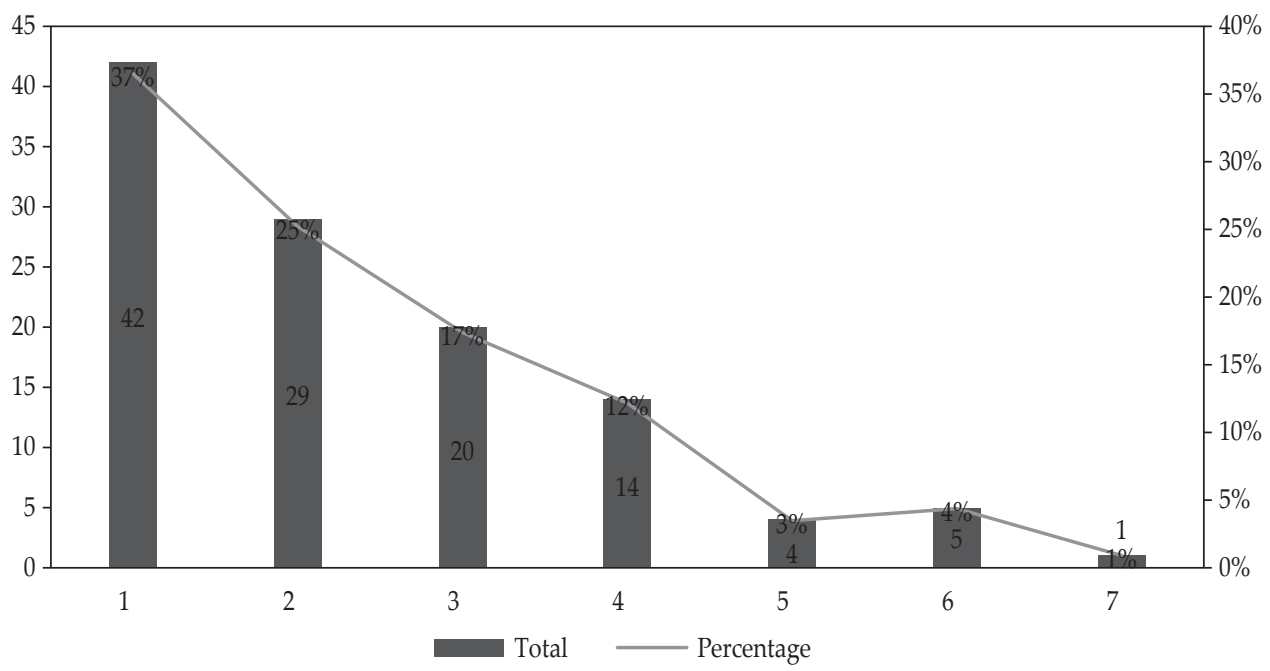

Source: Authors (2019)

Based on the data above, $37 \%$ (43 people) use one fintech brand, while $25 \%$ ( 29 people) use two fintech brands and one person uses seven fintech brands.

Figure 3.

\section{Users Amount of Fintech's Brand}

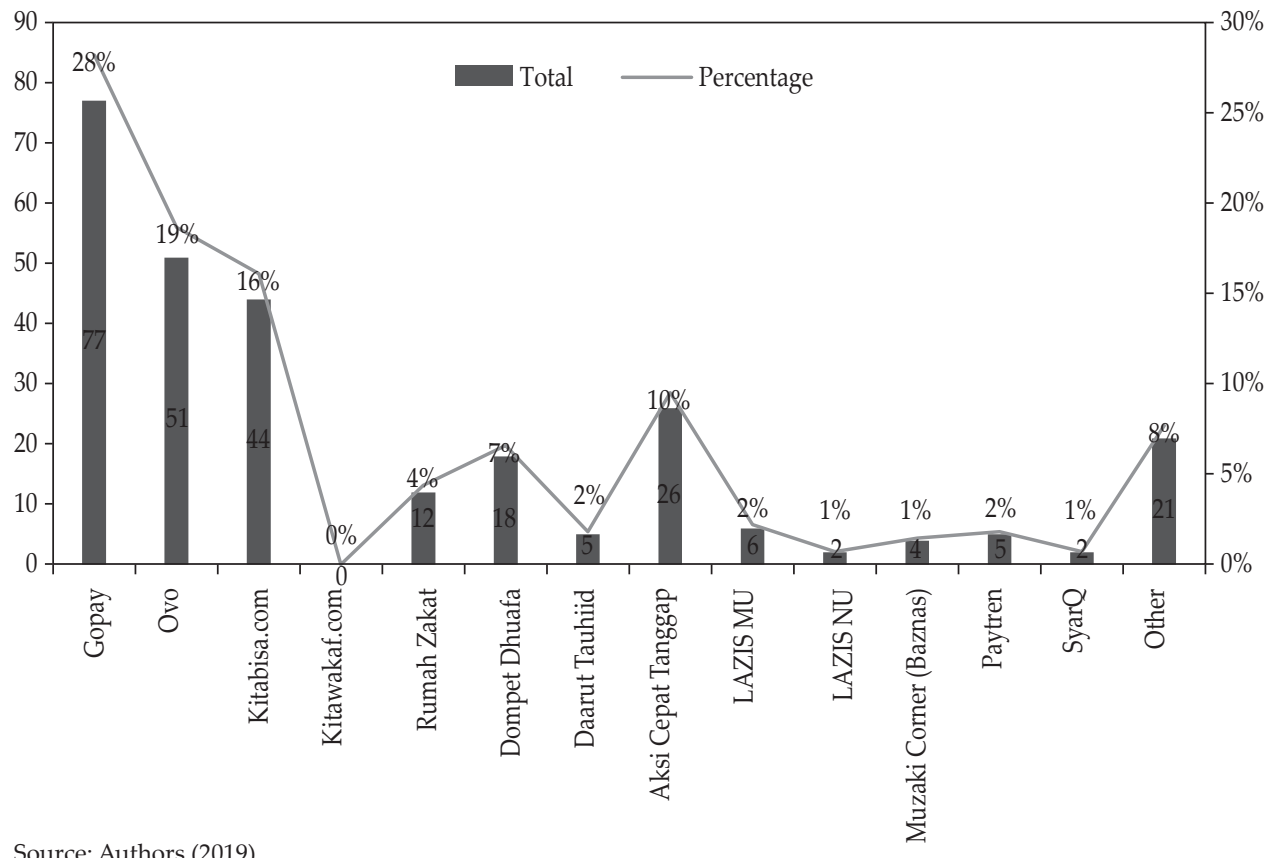

Source: Authors (2019) 
The data above shows that the use of Gopay is very dominant with a percentage of $28 \%$ (77 people), followed by OVO as much as 19\% (51 people), then Kitabisa. com as much as 16\% (44 people) and Aksi Cepat Tanggap reaching 10\% (26 people ), while others are only less than $10 \%$.

4.1.2. Validity and Reliability Test Result and Structural Equation Modeling

In this section, the results of the study will be shown by figure 4 . Based on that figure, validity and reliability test can be analyzed and the result is provided in Table 2. Afterwards, $\mathrm{R}$ square test value is provided in Table 3. Then, significant value as the last step of structural equation modeling is provided in Table 4.

Figure 4.

\section{Path Diagram t-value}

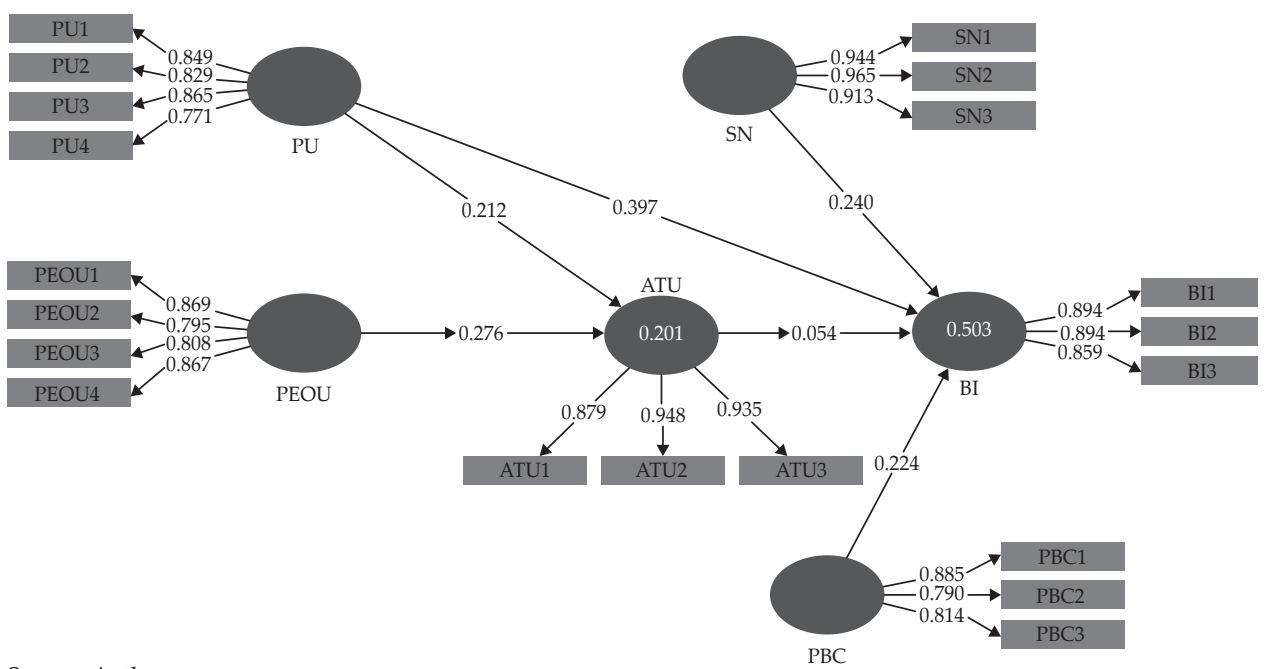

Source: Authors

Figure 4 above shows the amount of outer loading and Cronbach's Alpha values that can determine whether the study passed the validity and reliability tests. Further explanation regarding this will be explained in Table 2. While the $\mathrm{R}$ square value seen in figure 4 above will also be explained in Table 3 . Then, the original sample value for each variable path will be more clearly indicated in Table 4 at the same time with the p-value. 
Table 3.

Factor Analysis Result of All Measurement Items

\begin{tabular}{lccc}
\hline Constructs & Items & Outer Loading & Cronbach's Alpha \\
\hline Subjective Norm & SN1 & 0.944 & 0.936 \\
& SN2 & 0.965 & \\
\hline PN3 & PBC1 & 0.913 & 0.779 \\
Control & & 0.885 & \\
& PBC2 & & \\
& PBC3 & 0.79 & 0.85 \\
\hline Perceived Usefulness & PU1 & 0.814 & \\
& PU2 & 0.849 & \\
& PU3 & 0.829 & 0.857 \\
\hline Perceived Ease of Use & PU4 & 0.865 & \\
& PEOU1 & 0.771 & \\
& PEOU2 & 0.869 & 0.911 \\
& PEOU3 & 0.795 & \\
\hline Attitude Towards Usage & PEOU4 & 0.808 & 0.859 \\
& ATU1 & 0.867 & \\
\hline Behavioral Intention & ATU2 & 0.879 & \\
& ATU3 & 0.948 & \\
& BI1 & 0.935 & \\
\hline
\end{tabular}

Source: Authors

Based on the results obtained in Table 2, the question items have passed the validity and reliability test with the acquisition of the outer loading value and Cronbach's Alpha above 0.7. An indicator is valid if the value of outer loading 0.7 and reliable if the value of Cronbach's Alpha is 0.7 or more. The Cronbach's Alpha in this study is 0.936 (SN), 0.779 (PBC), 0.850 (PU), 0.857 (PEOU), 0.911 (ATU), and $0.859(\mathrm{BI})$.

$\mathrm{R}$ square value is the coefficient of determination in endogenous construct. According to Chin (1998), the category of $R$ square values was divided into three, i.e., strong (0.67), moderate (0.33) and weak (0.19). Table 3 below shows the value of $\mathrm{R}$ square on each endogenous variable in this study:

Table 4.

R Square Test Result

\begin{tabular}{lcc}
\hline & R Square & R Square Adjusted \\
\hline ATU & 0.201 & 0.187 \\
BI & 0.503 & 0.485 \\
\hline
\end{tabular}

Source: Authors (2019) 
Based on the table above, it can be concluded that ATU has a $\mathrm{R}^{2}$ value of 0.201, meaning that the ATU as an endogenous variable can be explained by its exogenous latent variables, i.e., PU and PEOU by $20 \%$ and the remaining $80 \%$ explained by other variables outside the research. Then BI has $\mathrm{R}^{2}$ value of 0.503 , meaning that BI endogenous variables can be explained by exogenous latent variables: SN, ATU, and PBC of 50.3\% and the remaining $49.7 \%$ are explained by other variables outside the research.

Table 5.

Hypothesis Relationship Path Test Result

\begin{tabular}{lccccc}
\hline Hypothesis & Path & $\begin{array}{c}\text { Original } \\
\text { Sample (O) }\end{array}$ & $\begin{array}{c}\text { T Statistics } \\
(\mid \text { O/STDEVI) }\end{array}$ & P Values & Result \\
\hline H1 & PU -> ATU & 0.212 & 0.843 & 0.4 & Not Supported \\
H2 & PEOU -> ATU & 0.276 & 1.786 & 0.075 & Not Supported \\
H3 & PU - BI & 0.397 & 4.724 & $0.000^{*}$ & Supported \\
H4 & ATU -> BI & 0.054 & 0.755 & 0.451 & Not Supported \\
H5 & SN -> BI & 0.24 & 3.606 & $0.000^{*}$ & Supported \\
H6 & PBC $>$ BI & 0.224 & 2.233 & $0.026^{*}$ & Supported \\
\hline
\end{tabular}

Note: ${ }^{*} \mathrm{P}<0.05$. Source: Authors

Hypothesis 1: Perceived Usefulness (PU) not significantly has a positive impact towards Attitude Towards Usage (ATU) of fintech to donate. This is based on the p-value of 0.400 which is greater than 0.05 . Thus, the first hypothesis is not supported.

Hypothesis 2: Perceived Ease of Use (PEOU) not significantly has a positive impact towards Attitude Towards Usage (ATU) of fintech to donate. This is based on the p-value of 0.075 which is greater than 0.05 . Thus, the second hypothesis is not supported.

Hypothesis 3: Perceived Usefulness (PU) significantly has a positive impact towards Behavioral Intention (BI) of using fintech to donate. This is based on the p-value of 0.000 which is smaller than 0.05 . Thus, the third hypothesis is supported. This positive relationship shows that the greater PU will also makes the greater BI of someone in donating using fintech.

Hypothesis 4: Attitude Towards Usage (ATU) not significantly has a positive impact towards Behavioral Intention (BI) of using fintech to donate. This is based on the p-value of 0.451 which is greater than 0.05 . Thus, the fifth hypothesis is not supported.

Hypothesis 5: Subjective Norm (SN) significantly has a positive impact toward Behavioral Intention (BI) of using fintech to donate. This is based on the p-value of 0.000 which is smaller than 0.05 . Thus, the sixth hypothesis is supported. This positive relationship shows that the greater SN will also makes the greater BI of someone in donating using fintech.

Hypothesis 6: Perceived Behavioral Control (PBC) significantly has a positive impact towards Behavioral Intention (BI) of using fintech to donate. This is based on the p-value of 0.026 which is smaller than 0.05 . Thus, the sixth hypothesis is supported. This positive relationship shows that greater PBC will also makes the greater BI of someone in donating using fintech. 


\subsection{Analysis}

\subsubsection{The Effect of PU Towards ATU}

The use of mobile phones in daily life today does not influence on the use of fintech to make donation. Indonesian people tend to choose donations in a conventional or practical way, such as through mosques, social institutions, or when there is a collection of social funds on the road, for example during disasters. Although donating using fintech can also be done easily, effectively and quickly, the community cannot confirm whether the funds are received directly by the beneficiaries who need the funds. However, fintech in Indonesia is still in its early stage and continue to develop so that the change in the community mindset from traditional method to modern by using the technology still cannot be applied in all daily activities.

The big potential of funding by donation using fintech also can provide any fundraising for small enterprises that need help without any profit sharing or return from lending. Research by Putu et al. (2018) showed that most of the MSMEs are ready to use fintech. However, the need of regulation and socialization of the use of fintech should be increased to cover the role of fintech in daily activities. Muzdalifa et al. (2018) also supported that regulation, infrastructure, human resource, and lack of financial literacy become a challenge to implement fintech.

\subsubsection{The Effect of PEOU Towards ATU}

In raising donations using crowdfunding mechanisms, fintech such as Kitabisa. com has been established since 2013 to charge 5\% fee to fundraisers. However, there is also a mechanism by fundraising organizations that pay marketing fees to Kitabisa.com. This is done for the continuity of the platform itself, especially for operational costs.

Philanthropic crowdfunding does not currently have official regulations from Financial Services Authority (Otoritas Jasa Keuangan/OJK) or Bank Indonesia. OJK provides regulations only related to peer-to-peer lending transactions (POJK Number 77/POJK.01/2016). However, this does not mean the OJK does not think of rules regarding raising donations using fintech.

Although fintech is easy to use at anytime and anywhere, not everybody uses it in the daily activity including donation. According to Rahma's research (2018), one of the informants also stated that he had not used the service because of the lack of understanding and lack of experience of informant on the use and benefit of fintech. Therefore, there should be adequate socialization and education as well as marketing related to this donation service using fintech. As Gopay and Ovo provide this information via pop-up information in the application.

Donation-based fintech can be used to facilitate data collection using big data management and analysis that allow fundraiser to make decision (Wulandari et al., 2018). This also helps the government and private institutions to obtain donation data reports and map the needs and potential that can have a greater impact on the welfare of the Indonesian people. 


\subsubsection{The Effect of PU Towards BI}

The result shows that there was an effect of PU on BI. This shows that one of the factors which driving good acceptance of a technology system is seen from how they perceive the benefits of the system, the higher the value of the perceived benefits felt will lead to a better attitude of someone in using the system. This proves that the use of fintech in donations is very beneficial for someone, such as donating become faster, more effective and easier can increase consumer's interest in donating with fintech especially for millennial's generation. This finding supported by the study of Chuang et al. (2016) in determining the consumer's intention to adopt fintech and Kim et al. (2016) that showed that perceived usefulness of payment-type fintech services positively influence intention to use. This study also supported by the research done by Won-jun (2018).

\subsubsection{The Effect of ATU Towards BI}

Different from TPB that proved that ATU has impact on BI, in this study shows that ATU has no impact on BI. This shows that even though fintech is convenient for donating, a good idea and liked by many, it does not necessarily affect consumer's intention of using a fintech to donate. Many consumers are still donating manually by giving directly to those who have the right to receive it.

Many people still cannot believe on the online system or fintech platforms. The reason is because there are some problems occurred, like scamming, identity theft, hacking, etc. Like the study done by Kim et al. (2016) showed that concern for information privacy of payment-type fintech services negatively effect on Intention to use. Those problems make bad evaluations and can influence people's attitude towards using fintech to make donations. They will choose to directly provide donations through institutions or directly to the targeted people.

\subsubsection{The Effect of SN Towards BI}

Subjective norms show how user perceptions about whether the people they consider important assume they have to use donations using fintech or not (direct donations or traditional ways). Many Internet users choose to use fintech to make donations because their friends or relatives use fintech and they recommend them to use. People tend to be easily influenced by their close people in making decisions. People whose opinions are important for them can influence them to do something.

If someone around them uses one of the fintech services to donate and is comfortable using it, they will recommend using the fintech. Because their opinions become important and they will believe that, they have to use fintech to make donations. This is supported by research conducted by Kim et al. (2016) that social influence of payment-type services has a positive effect on intention to use. Social influence can influence people opinion and decision to do something. Especially todays in digital era that what are posted in the Internet, using social media, online news or others can easily influence public opinion. Those public opinions can also influence our close person that will influence us. 


\subsubsection{The Effect of PBC Towards BI}

The perceived behavioral control describe the customer's perception if they have the resources and abilities needed to donate using fintech, then they will do it. To be able to donate using one of the fintech media, a gadget or cellphone and Internet service are needed. They also need a skill to use fintech so that users can make donations according to their wishes. If someone has a gadget or cellphone, Internet, and the ability to use fintech, then they will be able to cause the intention to donate using fintech.

People's perception that they will have resources and ability to make donations using fintech can motivate someone to intend to use fintech in donating. If it low perception, the intention to donate using fintech will be low, whereas if the perception is high, the intention to donate using fintech will be high. The stronger the belief in the availability of resources and the greater opportunities and the greater the resources, the stronger the individual PBC towards the interests. Anyone who has a high PBC will continue to be encouraged and successful because he believes in the resources and opportunities that exist, the difficulties he faces can be overcome.

\section{CONCLUSION AND RECOMMENDATION}

\subsection{Conclusion}

The results of the study explained that $\mathrm{BI}$ to donate using fintech was significantly affected by PU, SN and PBC. PU had the greatest impact on BI to donate using fintech (4.724), followed by SN (3.606) and PBC (2.233). When users feel the benefit and ease transacting using fintech, it will increase their interest to make donations. The result also shows that BI is not influenced by the ATU, nor do PU and PEOU affect ATU. This shows that one's intention is not continued with the attitude to donate using fintech. The perception of the ease and usefulness of fintech also does not make individuals comfortable and think that donate using fintech are good to do.

This research contributes to the literature regarding donations using fintech, which is still limited in number. Donations using fintech in Indonesia have great potential, but this related research is still limited in number. This research also contributes by providing understanding factors that influence people's intention to donate using fintech. In addition, this study also provides an overview of literacy towards fintech that $90 \%$ of respondents already know fintech and use it in their daily lives.

The most widely used fintech brands by respondents are Gopay with 77 people (28\%), OVO with 51 people (19\%) and Kitabisa.com with 44 people $(16 \%)$. Gopay and OVO are platforms for online transportation, but they also provide the donation services using e-wallet in an easy way. While the Kitabisa.com platform is a social fund crowdfunding platform. 


\subsection{Recommendation}

This research can provide an illustration that a generation of Indonesian Muslim millennial pays attention to the development of fintech in Indonesia, including in the donation service. This scheme of donation needs to be supported by adequate regulations to increase public confidence in donating using fintech.

This research also provides comprehensive analysis that can provide significant implication for future research both in academic or managerial fields. Future research can examine other variables for moderating or intervening that impact to behavioral intention and actual behavior in using fintech for other purposes. Managerial implication of this study can be explained that: First, fintech companies can use opportunity to enhance their financial service to facilitate more people in using fintech for daily activities for both business and social purpose; Second, government and fintech association also should to facilitate securities offering for donation-based crowdfunding models by proper regulation. Therefore, people will trust the institution and can donate safely; third, stakeholders who involve in Islamic social finances (zakat, waqf, infaq or sadaqah) also should to encourage third sector organization (zakat and waqf institutions, community empowerment, and others social institutions) to synergize with fintech companies in order to scale up realization of big potential the social fund. This synergy will provide more impact and benefit to beneficiaries, then it will help to increase maslahah and prosperity.

This study has several limitations that need to be corrected in the next study. First, the sample size in this study is still limited. This can complicate the generalization of research results. So that further research is expected to expand the coverage of samples that can represent each region in Indonesia. Second, this research needs to be added by in-depth interviews with stakeholders such as the fintech user community, fintech platform operators, government and social institutions.

\section{REFERENCES}

Accenture. (2012). Ready for Indonesia's Digital Future?. Retrieved from http:// ict4ngo.com/wp-content/uploads/Ready-for-Indonesias-Digital-FutureAccenture.pdf

Ajzen, I. (1991). The Theory of Planned Behavior. Organizational Behavior and Human Decision Processes 50, 179-211. Retrieved from https://doi.org/10.1016/07495978(91)90020-T

Asfarina, M., Ascarya., Beik, I.S. (2019). Classical and Contemporary Fiqh Approaches to Re-Estimating the Zakat Potential in Indonesia. Journal of Islamic Monetary Economics and Finance, 5(2), 387-419. Retrieved from https:// doi.org/10.21098/jimf.v5i2.1068

Bradford, S. C. (2012). Crowdfunding and the Federal Securities Laws. Columbia Business Law Review, 1-150. Retrieved from https://digitalcommons.unl.edu/ cgi/viewcontent.cgi?article=1118\&context=lawfacpub

Charities Aid Foundation. (2018). CAF World Giving Index 2018 A Global View of Giving Trends. Retrieved from https://www.cafonline.org/about-us/ publications/2018-publications/caf-world-giving-index-2018 
Chen, Y., Dai, R., Yao, J., Li., Y. (2019). Donate Time or Money? The Determints of Donation Intention in Online Crowdfunding. Sustainability, 11, 4269, 1-21. Retrieved from https://doi.org/10.3390/su11164269

Chuang, L. M., Liu, C. C., \& Kao, H. K. (2016). The Adoption of Fintech Service: TAM Perspective. International Journal of Management and Administrative Science (IJMAS), 3(7), 1-15. Retrieved from https://www.ijmas.org/vol3no72016.htm

Dapp, T., Slomka, L., AG, D. B., \& Hoffmann, R. (2014). Fintech-The digital (r) evolution in the financial sector. Deutsche Bank Research", Frankfurt am Main. Retrieved from http://www.dbresearch.com/PROD/ RPS_EN-PROD/PROD0000000000451941/Fintech_\%E2\%80\%93_The_ digital_\%28r\%29evolution_in_the_financia.pdf

Davis, F. D. (1989). Perceived Usefulness, Perceived Ease of Use, and User Acceptance of Information Technology. Management Information Systems Research Center, 13(3), 319-340. Retrieved from https://doi.org/10.2307/249008

Fenwick, M., McCahery, J.A., \& Vermeulen, E.PM. (2017). Fintech and the Financing of Entrepreneurs: From Crowdfunding to Marketplace Lending. ECGI Working Paper Series in Law. ISSN 2213-9419 Retrieved from http:// ssrn.com/abstract $=2967891$

Financial Stability Board. (2019). FinTech and Market Structure in Financial Services: Market Developments and Potential Financial Stability Implications. Retrieved from https://www.fsb.org/wp-content/uploads/P140219.pdf

Fishbein, M., \& Ajzen, I. (1975). Belief, Attitude, Intention, Behavior: An Introduction to Theory on Research. Addison-Wesley

Gujarati, D. N. (2004). Basic econometrics, Fourth Edition. The McGraw-Hill Companies.

Gulamhuseinwala, I., Bull, T., \& Lewis, S. (2015). FinTech is gaining traction and young, high-income users are the early adopters. Journal of Financial Perspectives, 3(3). Retrieved from https://papers.ssrn.com/sol3/papers. cfm?abstract_id=3083976

GSM Association. (2019). Connected Society, The State of Mobile Internet Connectivity 2019. Retrieved from https://www.gsma.com/ mobilefordevelopment/wp-content/uploads/2019/07/GSMA-State-of-MobileInternet-Connectivity-Report-2019.pdf

Hair, J. F., Sarstedt, M., Ringle, C. M., \& Mena, J. A. (2012). An assessment of the use of partial least squares structural equation modeling in marketing research. Journal of the academy of marketing science, 40(3), 414-433. Retrieved from https://link.springer.com/article/10.1007/s11747-011-0261-6

Hair, J.F, Sarstedt, M., Hopkins, L., \& G. Kuppelwieser, V. (2014). Partial least squares structural equation modeling (PLS-SEM) An emerging tool in business research. European Business Review, 26(2), 106-121. Retrieved from https:// www.emeraldinsight.com/doi/abs/10.1108/EBR-10-2013-0128

Henseler, J., Hubona, G., \& Ray, P. A. (2016). Using PLS path modeling in new technology research: updated guidelines. Industrial management $\mathcal{E}$ data systems, 116(1), 2-20. Retrieved from https://www.emeraldinsight.com/doi/ pdfplus/10.1108/IMDS-09-2015-0382.

Hulland, J. (1999). Use of partial least squares (PLS) in strategic management research: A review of four recent studies. Strategic management journal, 20(2), 
195-204. Retrieved from https://onlinelibrary.wiley.com/doi/abs/10.1002/ (SICI)1097-0266(199902)20:2\%3C195::AID-SMJ13\%3E3.0.CO;2-7

KPMG. (2019). The Pulse of Fintech 2019. Retrieved from https://kpmg.com/ fintechpulse

Kim, Y., Park, Y.J., Choi, J., \& Yeon, J. (2016). The Adoption of Mobile Payment Service for "Fintech". International Journal of Applied Engineering Research, 11(2), 1058-1061. Retrieved from https://pdfs.semanticscholar. org/2c96/8789b918883f6f189943f325b44aa69c9b9c.pdf

Langley, P. (2016). Crowdfunding in the United Kingdom: A cultural economy. Economic geography, 92(3), 301-321. Retrieved from https://www. tandfonline.com/doi/abs/10.1080/00130095.2015.1133233?casa_token=bCB_ VZhRAGQAAAAA:zE5_NgR_iLD2qZgCxjk31y--tlSEJ6mfQyQn9PRQIU7Eo2 pH4OrgLnx9J8d3ic95SPM5rn01AIPdyQ

Langley, P., \& Leyshon, A. (2017). Capitalizing on the crowd: The monetary and financial ecologies of crowdfunding. Environment and Planning A, 49(5), 1019-1039. Retrieved from https://journals.sagepub.com/doi/ abs/10.1177/0308518X16687556?casa_token=Swf-QYxQG68AAAAA:iGTlsEjK M82IMl6jZzvPop0mmqrkFzapvMH-ena38_6pwfX4MM9UDcL3G310ha5tA76 k5QLytqU

Leong, K., \& Sung, A. (2018). Fintech: What Is It and How Use Technologies to Create Business Value in Fintech Way?. International Journal of Innovation, Management and Technology, 9(2), 74-78. Retrieved from https://doi.org/10.18178/ ijimt.2018.9.2.791

Mannheim, K. (1952). Essays on the sociology of knowledge. Oxford, UK: Oxford University Press. Retrieved from https://doi.org/10.5840/ thought195328264

McKinsey\&Company. (2016). Unlocking Indonesia's Digital Opportunity. Retrieved from https://www.mckinsey.com/ /media/McKinsey/Locations/ Asia/Indonesia/Our\%20Insights/Unlocking\%20Indonesias\%20digital\%20 opportunity/Unlocking_Indonesias_digital_opportunity.ashx

Muzdalifa, I., Rahma, I.A., \& Novalia, B.G. (2018). Peran Fintech dalam Meningkatkan Keuangan Inklusif pada UMKM di Indonesia (Pendekatan Keuangan Syariah). Jurnal Masharif al-Syariah: Jurnal Ekonomi dan Perbankan Syariah, 3(1). Retrieved from http://journal.um-surabaya.ac.id/index.php/Mas/ article/view/1618/1306

Nasution, M.E., \& Usman, H. (2007). Proses Penelitian Kuantitatif. Jakarta: Lembaga Penerbitan Fakultas Ekonomi Universitas Indonesia

Pew Research Center. (2011). The Future of the Global Muslim Population, Projections for 2010-2030. Retrieved from http://assets.pewresearch.org/wpcontent/uploads/sites/11/2011/01/FutureGlobalMuslimPopulation-WebPDFFeb10.pdf

Pikkarainen, T., Pikkarainen, K., Karjaluoto, H., \& Pahnila, S. (2004). Consumer acceptance of online banking: an extension of the technology acceptance model. Internet research, 14(3), 224-235. Retrieved from https://www. emeraldinsight.com/doi/abs/10.1108/10662240410542652 
Pyöriä, P., Ojala, S., Saari, T., \& Järvinen, K. M. (2017). The millennial generation: a new breed of labour?. Sage Open, 7(1), 2158244017697158. Retrieved from https://journals.sagepub.com/doi/abs/10.1177/2158244017697158

Rahma, T. I. F. (2018). Persepsi Masyarakat Kota Medan terhadap Penggunaan Financial Technology (FINTECH). At-Tawasuth, 3(1), 642-661. Retrieved from http://jurnal.uinsu.ac.id/index.php/tawassuth/article/view/1704

Reinartz, W., Haenlein, M., \& Henseler, J. (2009). An empirical comparison of the efficacy of covariance-based and variance-based SEM. International Journal of research in Marketing, 26(4), 332-344. Retrieved from https://www.sciencedirect. com/science/article/pii/S0167811609000639

Rusydiana, A. S. (2018). Developing Islamic Financial Technology in Indonesia. Hasanuddin Economics and Business Review, 2(2), 143-152. Retrieved from https:// doi.org/10.26487/hebr.v2i2.1550

Ryu, Hyun-Sun. (2018). What Makes Users Willing or Hesitant to use Fintech? The Moderating Effect of User Type. Industrial Management and Data Systems, 113(3), 541-569. Retrieved from https://doi.org/10.1108/IMDS-07-2017-0325

Saksonova, S., \& Merlino, I.K. (2017). Fintech as Financial Innovation-The Possibilities and Problems of Implementation. European Research Studies Journal, 20(3A), 961-973. Retrieved from https://econpapers.repec.org/article/ ersjournl/v_3axx_3ay_3a2017_3ai_3a3a_3ap_3a961-973.htm

Taylor, S., \& Todd, P. A. (1995). Understanding information technology usage: A test of competing models. Information systems research, 6(2), 144-176. Retrieved from https://www.jstor.org/stable/23011007?seq=1\#page_scan_tab_contents

Venkatesh, V., \& Davis, F. (2000). A Theoritical Extension of the Technology Acceptance Model: Four Longitudinal Field Studies. Management Science, 46(2), 186-204. Retrieved from https://econpapers.repec.org/article/inmormnsc/ v_3a46_3ay_3a2000_3ai_3a2_3ap_3a186-204.htm

Vinzi, V. E., Chin, W. W., Henseler, J., \& Wang, H. (2010). Handbook of partial least squares (Vol. 201, No. 0). Berlin: Springer. Retrieved from https://link.springer. com/content/pdf/10.1007/978-3-540-32827-8.pdf

We Are Social. (2019). Digital 2019 Indonesia. Retrieved from https://andi.link/ hootsuite-we-are-social-indonesian-digital-report-2019/

Won-jun, Lee. (2018). Understanding Counsumer Acceptance of Fintech Service: An Extension of the TAM Model to Understand Bitcoin. IOSR Journal of Business and Management, 20(7), 34-37. Retrieved from https://doi. org/10.9790/487X-2007023437

Wulandari, P.P., Wijayanti, A., \& Fitriasari, R. (2018). Business Analysis and Designing Models of Governance and Also Risk Management for Fintech as Efforts of Financing Optimization in MSMEs. The International Journal of Accounting and Business Society, 26(2), 106-134. Retrieved from https://doi. org/10.21776/ub.ijabs.2018.26.2.5 